\title{
ANALISIS KADAR NITRIT DALAM AIR MEDIA PEMELIHARAAN LARVA IKAN KERAPU BEBEK SETELAH PROSES AERASI
}

\author{
Ahmad Rejito \\ Universitas Pendidikan Ganesha \\ Singaraja, Indonesia \\ e-mail: rejito89@gmail.com
}

\begin{abstract}
Abstrak
Penelitian ini bertujuan untuk mengetahui perubahan dan besar perubahan kadar nitrit dalam air media pemeliharaan larva ikan kerapu bebek setelah proses aerasi. Penelitian ini dilakukan selama sepuluh hari (umur larva 1 hari, 3 hari, 6 hari, 10 hari), hal ini dilakukan karena pada umur tersebut lava belum diberikan sirkulasi air dan juga larva masih sangat sensitif terhadap perubahan lingkungan. Hasil penelitian menunjukkan bahwa kadar nitrit mengalami penurunanan dan peningkatan tetapi tidak melampaui ambang batas yang dapat ditoleransi oleh ikan yaitu sebesar 0,5 ppm.
\end{abstract}

Kata kunci: Kadar Nitrit, Air Media Pemeliharaan Larva Ikan Kerapu Bebek,Proses Aerasi

\section{Pendahuluan}

Dalam pengelolaan pemeliharaan ikan kerapu bebek ada beberapa hal yang harus diperhatikan, yaitu pemeliharaan induk ikan, telur ikan, dan larva ikan. Dalam pemeliharaan ikan kerapu bebek ada beberapa aspek yang berpengaruh, antara lain aspek lingkungan, pakan, feeding regime, pengadukan air, dan intensitas cahaya. Dalam pemeliharaan larva ikan kerapu bebek, perubahan lingkungan sangat berperan. Hal ini disebabkan larva tersebut sangat resisten atau peka sekali terhadap perubahan lingkungan. Interaksi yang tidak serasi dengan lingkungan akan menyebabkan ikan stress, sehingga mekanisme pertahanan diri yang dimiliki menjadi lemah dan akhirnya mudah diserang penyakit.

Penyakit-penyakit yang menyerang ikan kerapu ada yang bersifat infektif, tetapi faktorfaktor non-infektif juga sangat berperan. Menurut Zonneveld dan kawan-kawan (1991), salah satu aspek yang berhubungan dengan faktor non-infektif adalah lingkungan tempat hidup ikan. Lingkungan tempat hidup ikan yang dimaksud adalah kualitas air media pemeliharaan yang vital bagi kehidupan ikan. Air media yang memadai, baik kuantitas maupun kualitasnya sangat menentukan keberhasilan pemeliharaan ikan. Kuantitas air media pemeliharaan dijaga agar ikan tidak mengalami stress, sedangkan kualitas air media dijaga agar keadaan air media tetap optimum bagi ikan sehingga dapat mencegah serangan penyakit.

Salah satu parameter yang dapat menyebabkan penurunan kualitas air media pemeliharaan larva adalah nitrit. Sumber-sumber pencemar yang diperkirakan dapat mempengaruhi kadar nitrit dalam air media pemeliharaan larva adalah sisa pakan baik alami maupun buatan, serta ikan yang mati. Sumber pencemar tersebut banyak mengandung bahan organik, terutama protein. Bahan tersebut merupakan media yang memungkinkan bagi kehidupan mikroorganisme, baik yang bersifat patogen maupun non-patogen.

Adanya bahan pencemar dalam air media pemeliharaan larva menyebabkan kadar oksigen terlarut menjadi berkurang. Sebagai akibat berkurangnya oksigen dalam air media maka proses dekomposisi terhadap bagian protein tidak dapat berlangsung sempurna menjadi nitrat, sehingga di dalam air mungkin terdapat nitrit $\left(\mathrm{NO}_{2}{ }^{-}\right)$atau campuran amonia $\left(\mathrm{NH}_{3}\right)$, nitrit $\left(\mathrm{NO}_{2}{ }^{-}\right)$, nitrat $\left(\mathrm{NO}_{3}{ }^{-}\right)$. Terdapatnya nitrit dalam air media pemeliharaan larva selain menyebabkan penurunan kualitas air, juga dapat menyebabkan keracunan pada larva ikan tersebut.

Air merupakan kebutuhan pokok dalam kegiatan pemeliharaan larva. Air yang digunakan untuk mengisi bak pemeliharaan larva berasal dari Laut. Air dialirkan secara langsung dari laut dengan menggunakan pipa sepanjang 50 meter dari daerah batas surut air laut terendah. Air laut sebelum dipakai untuk mengisi bak pemeliharaan larva diolah terlebih dahulu dengan sistem filter. Komponen filter yang digunakan adalah pasir, ijuk, batu kerikil, dan batu kerakal. Selain itu perlu diperhatikan kualitas air yang akan dipergunakan. Beberapa parameter yang harus diamati untuk menentukan kualitas air, antara lain: oksigen, karbondioksida, derajat 
keasaman $(\mathrm{pH})$, amonia, nitrit, suhu, hidrogen sulfida $\left(\mathrm{H}_{2} \mathrm{~S}\right)$, kesadahan, salinitas, kecerahan, dan pencemaran (Ghufran, 2004). Adanya bahan pencemar didalam air menyebabkan kadar oksigen terlarut menjadi berkurang. Sebagai akibat dari berkurangnya oksigen di dalam air maka proses dekomposisi terhadap bagian-bagian protein tidak dapat berlangsung sempurna menjadi nitrat, sehingga di dalam air mungkin terdapat nitrit $\left(\mathrm{NO}_{2}{ }^{-}\right)$atau campuran amonia $\left(\mathrm{NH}_{3}\right)$, nitrit $\left(\mathrm{NO}_{2}\right)$, nitrat $\left(\mathrm{NO}_{3}\right)$.

Adanya nitrit dalam air media pemeliharaan larva antara lain disebabkan oleh sisa pakan baik pakan alami maupun pakan buatan, ikan yang mati, dan juga air media itu sendiri yang diambil langsung dari laut, serta hasil buangan dalam penetasan telur ikan kerapu bebek, dimana semua bahan tersebut banyak mengandung protein. Adanya nitrit dalam air dapat menyebabkan gangguan terhadap kesehatan ikan, dimana kandungan nitrit dalam air media yang lebih besar dari 0,5 ppm dapat menyebabkan kematian ikan. Adanya nitrit dalam air media dapat menyebabkan terbentuknya " methaemoglobin" yang dapat menghambat perjalanan oksigen dalam tubuh, hal ini ditandai oleh darah ikan berwarna abu-abu kecoklatan (Ghufran, 2004). Pengaruh lainnya adalah dapat menimbulkan keadaan anaerob. Nitrit adalah bentuk peralihan (intermediate) oksidasi gas amoniak menjadi nitrat. Dengan adanya nitrit dalam air maka akan dibutuhkan oksigen yang cukup untuk proses oksidasi yang lebih sempurna dari nitrit menjadi nitrat. Apabila proses ini terjadi terus menerus maka suatu saat kadar oksigen terlarut dalam air akan semakin berkurang sehingga akhirnya menjadi habis, maka terjadilah keadaan anerob (Sudiana, 1990). Aerasi adalah suatu upaya penambahan udara pada medium pemeliharaan organisme dalam wadah terbatas. Fungsi aerasi adalah sebagai penyuplai oksigen, dan sebagai pengaduk air media pemeliharaan larva, serta mempercepat penguapan gas-gas beracun. Besar tingkat aerasi yang dipergunakan berpengaruh terhadap kelangsungan hidup larva ikan kerapu bebek (Cromileptes altivelis) pada stadia awal. Salah satu aspek yang berpengaruh terhadap perkembangan dan kelangsungan hidup larva stadia awal adalah hubungan dengan penanganan air media yaitu pengadukan air yang diberikan melalui aerasi. Pada stadia awal larva ikan kerapu bebek sangat sensitif terhadap perubahan lingkungan yang dapat menyebabkan stress dan kematian (Purba dan Ahmad, 1989).

Penentuan ion nitrit dalam air media pemeliharaan larva penting dalam menilai tingkat pencemaran. Adanya nitrit dalam air menunjukkan bahwa proses nitrifikasi belum sempurna, karena masih ada zat - zat organik yang belum diuraikan oleh bakteri-bakteri. Terdapatnya nitrit juga menunjukkan adanya penanganan limbah yang tidak sempurna. Nitrogen nitrit dapat diukur dalam jumlah yang sedikit sekali (Mahida, 1984). Ion nitrit dapat diidentifikasi dengan mereaksikannya dengan larutan asam sulfanilik dan alpha napthylamine sehingga terbentuk senyawa komplek berwarna merah.

Salah satu penanganan yang diberikan untuk mengatasi kekurangan oksigen dalam media pemeliharaan larva ikan adalah dengan penambahan oksigen terlarut ke dalam air media pemeliharaan tersebut dengan cara aerasi. Aerasi berfungsi sebagai penyuplai oksigen terlarut dan sebagai pengaduk sehingga air media tetap homogen. Dengan adanya pasokan oksigen secara terus-menerus ke dalam media pemeliharaan larva ikan, maka diharapkan proses dekomposisi protein dapat berlangsung sempurna, sehingga dapat mengurangi kadar nitrit dalam air media pemeliharaan ikan tersebut.

Dalam penelitian ini, yang dianalisis adalah perubahan kadar nitrit dalam air media pemeliharaan larva ikan kerapu bebek dari awal pemeliharaan $\left(D_{1}\right)$ sampai hari kesepuluh $\left(D_{10}\right)$. Hal ini dikarenakan pada kurun waktu tersebut larva masih sangat peka terhadap perubahan lingkungan, sehingga dalam air media pemeliharaan belum diberi sirkulasi air, tetapi hanya diberikan aerasi. Permasalahan yang timbul adalah bagaimanakah perubahan dan seberapa besar perubahan kadar nitrit dalam air media pemeliharaan larva ikan kerapu bebek setelah proses aerasi. Untuk itu penelitian ini bertujuan untuk mengetahui perubahan dan besarnya peubahan kadar nitrit dalam air media pemeliharaan larva ikan kerapu bebek setelah proses aerasi. Hasil penelitian ini dapat dimanfaatkan sebagai petunjuk adanya pencemaran nitrit dalam air media pemeliharaan larva, acuan dalam menanggulangi pencemaran air oleh nitrit dalam air media pemeliharaan, bahan pertimbangan untuk penelitian selanjutnya.

\section{Metode}

Penelitian ini merupakan penelitian eksperimen yang bertujuan untuk mengetahui perubahan dan besar perubahan kadar nitrit pada air media pemeliharaan larva ikan kerapu bebek yang diberikan aerasi dari awal pemeliharaan $\left(D_{1}\right)$ sampai larva berumur 10 hari $\left(D_{10}\right)$. Hal ini dikarenakan pada usia tersebut belum dilakukan penggantian air (resirkulasi) pada air 
media pemeliharaan sehingga pengenceran senyawa beracun dan pembuangan sisa pakan serta larva ikan yang mati tidak ada. Penelitian ini dilakukan dengan mengukur konsentrasi nitrit dalam air media pemeliharaan larva dengan menggunakan alat spektronik 1201.

Jenis data yang dikumpulkan adalah data kuantitatif tentang konsentrasi nitrit dalam air media pemeliharaan larva kerapu bebek yang diambil pada awal pemeliharaan, umur larva ikan 3 hari $\left(D_{3}\right)$, umur larva ikan 6 hari $\left(D_{6}\right)$, dan umur larva ikan 10 hari $\left(D_{10}\right)$ hari. Sampel air media diambil secara bebas dalam bak pemeliharaan larva ikan kerapu bebek dengan pertimbangan bahwa air dalam bak telah homogen akibat adanya aerasi. Pengambilan sampel untuk masing - masing pemeriksaan diulang sebanyak 3 kali. Sampel air yang sudah diambil kemudian langsung dianalisis kadar nitritnya dengan alat spektrofotometer (spektronik 1201). Dilakukan juga pengukuran $\mathrm{pH}$ dan suhu sebagai data tambahan. Secara rinci pengumpulan data penelitian dilakukan melalui tahapan kegiatan sebagai berikut.

Dipersiapkan peralatan seperti tabung reaksi, pipet ukur ( $1 \mathrm{~mL}, 5 \mathrm{~mL}, 10 \mathrm{~mL}$, dan $50 \mathrm{~mL}$ ), mikro pipet $(0,1 \mathrm{~mL}, 0,25 \mathrm{~mL}$, dan $0,5 \mathrm{~mL})$, gelas beker $(25 \mathrm{~mL}$ dan $50 \mathrm{~mL})$, labu ukur $(100 \mathrm{~mL}$ dan $50 \mathrm{~mL}$ ), spektrofotometer (Spektronik 1201), botol sampel $100 \mathrm{~mL}, \mathrm{pH}$ meter, termometer, kertas tissue. Bahan yang dipersiapkan adalah larutan asam sulfanilik (Reagen A), larutan $\alpha$ naftilamin (Reagen $\mathrm{B}$ ), aquades bebas $\mathrm{NO}_{2}$, larutan standar nitrit $500 \mathrm{ppm}$.

Dari penelitian ini diperoleh data mengenai kadar nitrit dalam air media pemeliharaan larva ikan kerapu bebek pada awal pemeliharaan $\left(D_{1}\right)$, umur 3 hari $\left(D_{3}\right)$, umur 6 hari $\left(D_{6}\right)$, dan umur 10 hari $\left(D_{10}\right)$, masing-masing sebanyak 3 kali pengulangan. Data hasil pengulangan kemudian dirata-ratakan sehingga diperoleh data tunggal konsentrasi (ppm) nitrit dalam air media untuk masing - masing umur larva $\left(D_{1}, D_{3}, D_{6}, D_{10}\right)$. Data konsentrasi nitrit tersebut kemudian dibandingkan untuk mengetahui perubahan kadar nitrit yang terjadi selama proses aerasi. Untuk lebih memudahkan dalam melihat perubahan kadar nitrit yang terjadi untuk setiap waktu pengambilan sampel (pada awal pemeliharaan, umur 3 hari, umur 6 hari, dan umur 10 hari) data disajikan dalam bentuk tabel dan grafik.

\section{Hasil dan Pembahasan}

Setelah dilakukan penelitian di Laboratorium Kimia Balai Besar Riset Perikanan dan Budidaya Laut Gondol terhadap sampel air media pemeliharaan larva ikan kerapu bebek pada sebuah bak pemeliharaan larva, diperoleh data kadar nitrit dalam air media tersebut seperti ditunjukkan pada Tabel 1.

Tabel 1. Kadar Nitrit (ppm) pada Air Media Pemeliharaan Larva Ikan Kerapu Bebek

\begin{tabular}{ccccc}
\hline Umur Larva & \multicolumn{3}{c}{ Kadar nitrit ( ppm ) } & $\begin{array}{c}\text { Rata } \text { rata } \\
\text { kadar nitrit }\end{array}$ \\
\cline { 2 - 4 } & Ulangan I & Ulangan II & Ulangan III & 0,083 \\
1 hari $\left(D_{1}\right)$ & 0,084 & 0,084 & 0,081 & 0,024 \\
3 hari $\left(D_{3}\right)$ & 0,026 & 0,023 & 0,023 & 0,276 \\
6 hari $\left(D_{6}\right)$ & 0,274 & 0,274 & 0,278 & 0,109 \\
10 hari $\left(D_{10}\right)$ & 0,109 & 0,109 & 0,109 & \\
\hline
\end{tabular}


Tabel 2. Derajat Keasaman $(\mathrm{pH})$ dan Suhu Air Media Pemeliharaan Larva Ikan Kerapu Bebek

\begin{tabular}{|c|c|c|c|c|c|c|}
\hline \multirow[b]{2}{*}{$\begin{array}{l}\text { Umur } \\
\text { Larva }\end{array}$} & \multicolumn{3}{|c|}{ pH } & \multicolumn{3}{|c|}{ Suhu $\left({ }^{\circ} \mathrm{C}\right)$} \\
\hline & $\begin{array}{c}\text { Pemeriksa } \\
\text { an I }\end{array}$ & $\begin{array}{c}\text { Pemeriksa } \\
\text { an II }\end{array}$ & $\begin{array}{c}\text { Pemeriksa } \\
\text { an III }\end{array}$ & $\begin{array}{c}\text { Pemeriksa } \\
\text { an I }\end{array}$ & $\begin{array}{c}\text { Pemeriksa } \\
\text { an II }\end{array}$ & $\begin{array}{c}\text { Pemeriksa } \\
\text { an III }\end{array}$ \\
\hline \multicolumn{7}{|l|}{1 hari } \\
\hline Pagi & 8,1 & 8,1 & 8,1 & 27,0 & 27,0 & 27,0 \\
\hline Sore & 8,3 & 8,3 & 8,3 & 28,7 & 28,7 & 28,7 \\
\hline \multicolumn{7}{|l|}{3 hari } \\
\hline Pagi & 8,4 & 8,4 & 8,4 & 27,5 & 27,5 & 27,5 \\
\hline Sore & 8,5 & 8,5 & 8,5 & 28,8 & 28,8 & 28,8 \\
\hline \multicolumn{7}{|l|}{6 hari } \\
\hline Pagi & 8,6 & 8,6 & 8,6 & 27,6 & 27,6 & 27,6 \\
\hline Sore & 8,6 & 8,6 & 8,6 & 28,7 & 28,7 & 28,7 \\
\hline \multicolumn{7}{|l|}{ 10hari } \\
\hline Pagi & 8,8 & 8,8 & 8,8 & 27,9 & 27,9 & 27,9 \\
\hline Sore & 8,8 & 8,9 & 8,8 & 28,7 & 28,7 & 28,7 \\
\hline
\end{tabular}

Untuk lebih memudahkan dalam melihat perubahan kadar nitrit yang terjadi dalam air media pemeliharaan larva ikan kerapu bebek setelah proses aerasi selama 10 hari, maka data dalam Tabel 2 disajikan dalam bentuk grafik seperti ditunjukkan pada Gambar 2.

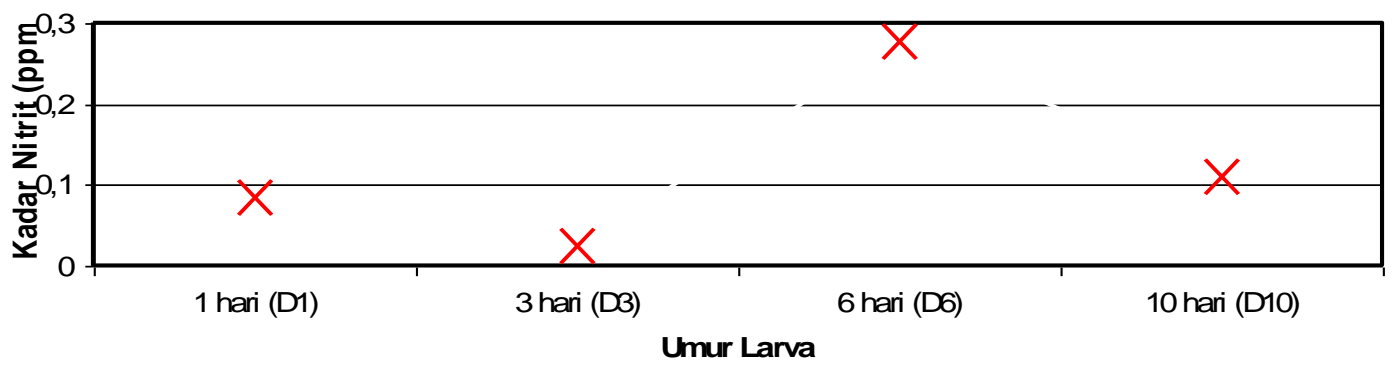

Gambar 1. Grafik Kadar Nitrit Dalam Air Media Pemeliharaan Larva Ikan Kerapu Bebek Setelah Proses Aerasi

Dari gambar 2 terlihat ada penurunan dan peningkatan kadar nitrit dalam air media pemeliharaan larva ikan kerapu bebek selama proses aerasi. Pada umur larva 1 hari diperoleh kadar nitrit sebesar $0,083 \mathrm{ppm}$ yang berasal dari bak penetasan telur (umur larva 0 hari -1 hari). Ini merupakan kadar nitrit awal dalam air media yang belum diberi proses aerasi, atau dengan kata lain digunakan sebagai kontrol. Pada umur larva $1-3$ hari $\left(D_{1}-D_{3}\right)$ terlihat adanya penurunan kadar nitrit dari $0,083 \mathrm{ppm}$ menjadi $0,024 \mathrm{ppm}$. Hal ini dikarenakan pada umur $1-3$ hari $\left(D_{1}-D_{3}\right)$ larva belum diberikan pasokan makanan, sehingga tidak ada sisa pakan yang dapat mempengaruhi kadar nitrit dalam air media pemeliharaan larva tersebut. Proses aerasi yang diberikan secara terus menerus dalam air media pada umur tersebut hanya dapat menurunkan kadar nitrit sebesar $0,059 \mathrm{ppm}$ saja, dan air media pemeliharaan masih mengandung nitrit sebesar $0,024 \mathrm{ppm}$. Nitrit tersebut diduga berasal dari larva yang mati dan mengalami dekomposisi. Karena dekomposisi tersebut berjalan bertahap, maka proses aerasi yang bertujuan untuk meningkatkan kandungan oksigen terlarut tidak dapat digunakan sepenuhnya untuk proses dekomposisi protein. Selain itu, oksigen yang disuplai melalui aerasi tidak hanya digunakan untuk menguraikan bahan kimia yang ada di dalam air media, tetapi juga dipergunakan untuk proses respirasi oleh organisme yang ada didalam air media tersebut, termasuk larva.

Dari data pada Tabel 2, pada umur larva $3-6$ hari $\left(D_{3}-D_{6}\right)$ terlihat adanya peningkatan kadar nitrit sebesar 0, $252 \mathrm{ppm}$ (dari 0,024 ppm menjadi 0,276 ppm). Pada umur tersebut larva belajar mencari sumber energi dari luar, karena satu-satunya sumber energi untuk metabolisme larva berupa kuning telur sudah habis. Pada masa ini larva diberikan makanan berupa pakan alami seperti rotifera dan plankton. Fase ini merupakan masa kritis bagi larva, sebab kemampuan untuk memperoleh sumber energi dari luar masih kurang. Hal ini disebabkan oleh kecepatan renang larva masih rendah, sehingga keberhasilan untuk menangkap pakan juga rendah. Agar peluang bertemu antara larva dengan rotifera cukup tinggi, maka larva diberikan 
konsentrasi rotifera yang tinggi (Lubzens et.al, 1985). Kematian larva pada fase ini tinggi karena larva baru belajar mencari makanan dari luar akibat kehabisan pasokan makanan dari dalam tubuhnya. Hal ini sesuai dengan hasil penelitian Yasunaga (1975), bahwa mortalitas yang tinggi terjadi pada dua periode, periode pertama pada saat kuning telur habis diserap sehingga larva mulai mendapat makanan dari luar, dan periode kedua adalah pada saat larva berubah menjadi benih. Kematian pakan alami (rotifera dan plankton) juga mempengaruhi kadar nitit pada fase ini. Kematian rotifera dan plankton diakibatkan oleh perbedaan lingkungan dimana mereka dipakai sebagai pakan alami dan lingkungan dimana mereka dibudidayakan (kultur) yang merupakan persiapan sebagai pakan alami.

Dibandingkan dengan pada fase I (umur larva $1-3$ hari), maka pada fase II (umur larva $3-6$ hari) ini lebih banyak terdapat bahan organik yang mengalami dekomposisi. Dekomposisi bahan organik berasal dari ikan yang mati dan sisa pakan, sehingga pengaruh aerasi tidak dapat menurunkan kadar nitrit jika dibandingkan dengan fase I. Tetapi pada fase II ini terjadi proses nitrifikasi, hal ini terbukti dengan adanya data tambahan berupa $\mathrm{pH}$ dan suhu yang mendukung terjadinya proses nitrifikasi. Dari data pada Tabel 4.2 terlihat pada fase II (umur larva $3-6$ hari) $\mathrm{pH}$ air media berkisar antara $8,4-8,6$, sedangkan suhu air media berkisar antara $27,5-28,8^{\circ} \mathrm{C}$. suhu dan $\mathrm{pH}$ tersebut sesuai dengan kondisi optimum untuk terjadinya nitrifikasi, yaitu pH antara $8,3-9,3$ dan suhu antara $26,7^{\circ} \mathrm{C}-32,3^{\circ} \mathrm{C}$ (Sudiana, 1990).

Pada umur larva $6-10$ hari $\left(D_{6}-D_{10}\right)$ terlihat adanya penurunan kadar nitrit sebesar 0 , $167 \mathrm{ppm}$ (dari 0,0276 ppm menjadi 0,109 ppm). Pada umur ini merupakan fase kelanjutan dan penyesuaian terhadap pencarian makanan dari luar, sehingga hanya sedikit larva yang mati. Pada umur ini yang mempengaruhi kadar nitrit hanya sisa pakan saja. Pada fase ini, aerasi berpengaruh dalam penurunan kadar nitrit, disebabkan oleh kebutuhan bahan kimia terhadap oksigen berkurang dibandingkan pada fase kedua (umur larva 3-6 hari).

Dari Tabel 4.1, bila dilihat perubahan kadar nitrit dari awal pemeliharaan $\left(D_{1}\right)$ sampai umur larva 10 hari $\left(D_{10}\right)$ ternyata mengalami peningkatan. Peningkatan terjadi terutama pada umur larva $3-6$ hari. Walaupun terjadi penurunan kadar nitrit pada umur larva $1-3$ hari dan 6 - 10 hari, tetapi penurunan tersebut tidak menyebabkan berkurangnya kadar nitrit dalam air media, malahan meningkat. Hal ini dikarenakan banyaknya bahan organik terutama protein yang mengalami penguraian dalam air media pemeliharaan larva tersebut, yang mana sumber bahan organik tersebut adalah larva dan pakan alami yang mati. Walaupun demikian, kadar nitrit dalam air media pemeliharaan larva ikan kerapu bebek belum melampaui ambang batas yang dapat ditoleransi oleh ikan tersebut yaitu sebesar 0,5 ppm. Kadar nitrit dalam air media pemeliharaan larva yang melebihi $0,5 \mathrm{ppm}$ dapat menyebabkan kematian ikan (Ghufran, 2004).

Dari Tabel 4.2, nilai pH berkisar antara $8-8,9$ dan suhu berkisar antara 27,0 - 28,8. Suhu dan $\mathrm{pH}$ air media pemeliharaan larva ikan kerapu bebek ini cukup mendukung berlangsungnya reaksi nitrifikasi secara sempurna. Nitrifikasi terjadi pada nilai $\mathrm{pH}$ diatas 5,5 dengan $\mathrm{pH}$ optimum antara $8,3-9,3$, sedangkan suhu yang paling menguntungkan untuk terjadinya nitrifikasi adalah $26,7{ }^{\circ} \mathrm{C}-32,3^{\circ} \mathrm{C}$ (Sudiana, 1990). Dengan demikian, suhu dan $\mathrm{pH}$ pada air media bukanlah faktor penyebab adanya nitrit dalam air media pemeliharaan larva ikan kerapu bebek karena sudah sesuai dengan kondisi optimum untuk terjadinya proses nitrifikasi secara sempurna.

Proses aerasi yang diberikan secara terus menerus akan meningkatkan kandungan oksigen terlarut yang akan digunakan oleh mahluk hidup yang ada di dalam air media untuk respirasi dan membantu metabolisme. Oksigen terlarut juga digunakan oleh bahan kimia yang ada dalam air media tersebut untuk keperluan oksidasinya. Jika tidak adanya aerasi maka kandungan oksigen terlarut menjadi berkurang, bisa jadi akan mencapai titik nol yang menyebabkan kematian total pada larva dan pakan alami dalam media buatan.

\section{Simpulan dan Saran}

Dari hasil penelitian yang dilakukan dapat disimpulkan bahwa :

1. Kadar nitrit dalam air media pemeliharaan larva ikan kerapu bebek mengalami penurunanan dan peningkatan setelah proses aerasi tetapi tidak melampaui ambang batas yang dapat ditoleransi oleh ikan yaitu sebesar 0,5 ppm yang dapat menyebabkan kematian ikan.

2. Besarnya perubahan kadar nitrit setelah proses aerasi dalam air media pemeliharaan larva ikan kerapu bebek adalah sebagai berikut :

Pada umur larva $1-3$ hari $\left(D_{1}-D_{3}\right)$ terlihat adanya penurunan kadar nitrit sebesar 0,059 dari $0,083 \mathrm{ppm}$ menjadi $0,024 \mathrm{ppm}$. 
- Pada umur larva $3-6$ hari $\left(D_{3}-D_{6}\right)$ terlihat adanya peningkatan kadar nitrit sebesar 0 , $252 \mathrm{ppm}$ dari $0,024 \mathrm{ppm}$ menjadi $0,276 \mathrm{ppm}$

Pada umur larva $6-10$ hari $\left(D_{6}-D_{10}\right)$ terlihat adanya penurunan kadar nitrit sebesar 0 , $167 \mathrm{ppm}$ dari $0,276 \mathrm{ppm}$ menjadi $0,109 \mathrm{ppm}$

Saran

Setelah dilakukan penelitian penulis mengajukan beberapa saran yaitu :

1. Penelitian ini merupakan penelitian dasar sehingga perlu dilakukan penelitian lebih lanjut tentang cara penanganan senyawa nitrit yang lebih mudah dan cepat.

2. Bagi para pembudidaya ikan diharapkan menciptakan kondisi optimum bagi ikan salah satunya adalah pengurangan kadar nitrit.

\section{Daftar Pustaka}

Apha dan Awwa WPCF. 1971. Standard Method for Examination of Water and Waste Water. Edition 15. New York : RR Ronnelly \& Sons Company.

Davy, F. B and A. Chouinard. 1980. Induced Fish Breeding in Southeast Asia. Report of Workshop Held in Singapore.

Depkes RI. Buku Petunjuk Pengambilan Contoh Air dan Pemeriksaan Kimia di Lapangan.

Depkes RI. 1988. Laporan Penataran / Latihan Toksikologi Bahan Kimia dan Pestisida. Buku III. Yogyakarta.

Effenddy, M. I. 1979. Metoda Biologi Perikanan. Cetakan pertama, Penerbit Yayasan Dewi.

Fulks, W and K. L. Main. 1991. Rotifera and Microalgae Culture Systems. Proceedings of U. S. Asia Workshop. The Oceanic Institute. Honolulu. Hawaii.

Ghufran H.Kordi K, M. 2004. Penanggulangan Hama dan Penyakit Ikan. Jakarta. Rineka Cipta, $170-189$.

Joko Tri Purnomo. 2001. Pengaruh Kecepatan Aerasi Terhadap Kecepatan Penetasan, Daya Tetas Telur dan Kelangsungan Hidup Larva Ikan Kerapu Bebek (Cromileptes altivelis Valenciennes) Stadia Awal. Skripsi (tidak diterbitkan). Fakultas Perikanan dan IImu Kelautan Universitas Diponegoro Semarang.

Lubzens, E et.al. 1989. Rotiferas as Food in Aquaculture. National Center for Magriculture. Israel Oceanographie \& Limnological Research. Israel. Hydrobiologia, 186/187 : 387 400.

Mishima, H. and B. Gonzales. 1994. Some Biological and Ecology Effects on

Cromileptes altevelis Araound Palawan Island, Philippnes. Suisanzoskoku 42 (2) : 345 - 349.

Purba, R dan T. Akhmad. 1989. Review Hasil Penelitian Budidaya Kerapu. Makalah Penelitian Budidaya Pantai. Sub Balai Penelitian Budidaya Pantai Bojonegoro, Serang.

Puslitbang Perikanan. 1990. Field Guide to Groupers of Southeast Asia. Departemen Pertanian, Badan Penelitian dan Pengembangan Pertanian. Jakarta.

Sudiana, I Ketut. 1990. Analisis Nitrit Dalam Air Sumur Gali di Kelurahan Kampung Baru Kecamatan Buleleng Kabupaten Buleleng Tahun 1989. Skripsi (tidak diterbitkan). Jurusan Pendidikan MIPA, FKIP Udayana.

Riyadi, Slamet. 1984. Pencemaran Air. Surabaya : Karya Anda

Surbakty, B. M. 1986. Air Minum Sehat. Edisi Pertama. Surabaya : Mutiara Solo 
Sugama, K., Artaty Wijono. 1995. Teknologi Pembenihan dan Pengadaan Ikan Laut. Prossiding Temu Usaha Pemasyarakatan Teknologi Keramba Jaring Apung Bagi Budidaya Laut. Jakarta.

Ticoalu, G. A. 1984. Pencemaran Air Dan Pemanfaatan Limbah Industri.Terjemahan U.N. Mahida. Water Pollution and Disposal of Waste Water on Land. Tahun 1981. Cetakan I. Jakarta : CV Rajawali

Watanabe, T. 1983. Fish Nutrition and Mariculture. JICA Text Book. The General Aquaculture Course. Tokyo

Watanabe, T et.al. 1983. Nutritional Value of Live Organism Used In Japan for Mass

Propagation of Fish : A Review. Aquaculture, 34 : $115-143$ 